\title{
Cikkismertetés: Feladatalapú, csoportos testsúlykezelési program randomizált, kontrollált vizsgálata és gazdasági értékelése
}

\author{
Article review: Randomised controlled trial and economic evaluation \\ of a task-based weight management group programme
}

Ismertető: Wolher Veronika $\square$

Pécsi Tudományegyetem, Általános Orvosi Kar, Orvosi Népegészségtani Intézet, Pécs

Ismertetett cikk: McRobbie, H., Hajek, P., Peerbux, S., Kahan, BC., Eldridge, S., Trépel, D., Parrott, S., Griffiths, C., Snuggs, S., Smith, KM. (2019) Randomised controlled trial and economic evaluation of a task-based weight management group programme. BMC Public Health, 19:365. https://doi.org/10.1186/s12889-019-6679-3

Beküldve: $\quad$ 2020. 05. 08.

doi: $\quad$ 10.24365/ef.v61i3.596

Kulcsszavak: testsúlykezelés; elhízás; testsúlycsökkentés; költséghatékonyság

Keywords: weight management; obesity; weight loss; cost-effectiveness

Az elhízás növekő globális fenyegetést jelent az egészségre nézve, és fő hozzájáruló tényező az egészségegyenlőtlenségekhez. Olyan testsúlyszabályzó programok szükségesek, amelyek hatékonyak, gazdaságosak és elérnek a hátrányos helyzetû rétegekhez is. Az adott vizsgálat során olyan összetett, csoportos intervenciót végeztek, amely hátrányos közösségekből származó ügyfelek számára is alkalmazható volt. Kutatták, hogy ennek a testsúly cselekvési programnak (Weight Action Programme; WAP) jobbak-e az eredményei egy év alatt, mint az alapellátásban alkalmazott alap-testsúlyszabályzási programnak, amelyet a háziorvosok mellett dolgozó ápolók végeznek (Intervention delivered by practice nurses; PNI). A randomizált, kontrollált vizsgálat során 330 elhízott felnőttet toboroztak a Londonban múködő háziorvosi körzetekből, és őket sorolták be vagy a WAP programban ( $n=221$ ) való részvételre, mely nyolc héten keresztül heti konzultációt biztosított a résztvevőknek, vagy a PNI programba
( $n=109$ ), amely szintén nyolc hétig tartott, de négy konzultációt foglalt magába. Mindkét beavatkozás táplálkozásra, fizikai aktivitásra és önmegfigyelésre irányuló feladatokat, tevékenységeket, javaslatokat tartalmazott. Az elsődleges végpont a kiindulástól számított 12 hónap elteltével a testsúlyban bekövetkezett változás volt. A Nemzeti Egészségügyi Szolgálat (National Health Service; NHS) számára költséghatékonysági elemzéseket végeztek a WAPpal kapcsolatos költségekre és életminőséggel korrigált életévekre (Quality-Adjusted Life-Years; QALYs) vonatkozóan. 2012 szeptemberétől 2014 januárjáig toborozták a vizsgálatban résztvevőket, és az utánkövetés 2015 februárjában fejeződött be. A vizsgálatban a legtöbb résztvevő munkanélküli volt, és 60\%-uk etnikai kisebbséghez tartozott. A résztvevő́k 88\%-a mindegyik vizsgálati ágban eljutott legalább egy regisztrált végponthoz, és így bekerülhettek az elsődleges elemzésbe. Összehasonlítva a két módszert, a testsúly cselekvési program 
(WAP) összességében nagyobb testsúlycsökkenést eredményezett (- 4,2 kg kontra - 2,3 kg; különbség = 1,9 kg, 95\%-os megbízhatósági tartomány, MT: $3,7 ;-0,1 ;$ p-érték $=0,04)$, és nagyobb valószínűséggel eredményezett legalább 5\%-os testsúlycsökkenést 12 hónap alatt az alapellátásban lévő alap-testsúlyszabályzási beavatkozáshoz képest (41\% kontra 27\%, esélyhányados, $\mathrm{EH}=14,61$ 95\% MT: 2,32;
91,96, p-érték=0,004). A növekményi költséghatékonysági rátát (incremental cost-effectiveness ratio; ICER) nézve a WAP magasan költséghatékonyabb volt (£7742/QALY) a PNI-vel szemben. A vizsgálatban értékelt, feladatalapú cselekvési program mintaként szolgálhat hatásos és gazdaságos testsúlycsökkentési programokhoz hátrányos helyzetű közösségekből származó ügyfelek számára is.

\section{TANULSÁGOK A HAZAI SZAKEMBEREK SZÁMÁRA}

Olyan testsúlycsökkentő programokat kell összeállítani, amelyek hosszú ideig tartanak, és rendszeres kapcsolattatást tesznek lehetővé a programban résztvevők és a programot vezetők közt. Mindemellett egyértelmú feladatokkal és ezek elvégzésének visszacsatolásával segítik a programban résztvevőket és ezzel a program sikerességét. A jól kidolgozott, feladatalapú testsúlycsökkentési programok hatásosak és gazdaságosak lehetnének hátrányos helyzetú csoportok számára is. 